\title{
Analysis of Complaint and Suggestion value at Public Services for Organizational Success
}

\author{
Nunik Madyaningarum ${ }^{1}$, Gustini Sayid ${ }^{2}$ \\ \{nunikarum@gmail.com ${ }^{1}$, gtien@batan.go.id ${ }^{2}$ \} \\ Pusat Teknologi Bahan Galian Nuklir-BATAN, Jl. Lebak bulus raya no9,pasar jumat, \\ Jakarta and 12440, Indonesia ${ }^{1,2}$
}

\begin{abstract}
Complaints are expensive, both as direct and indirect costs. Organizational responses are the initial reactions by a company in response to a complaint. Analysis of frequency descriptive statistics was conducted on data derived from 71 customer satisfaction assessment questionnaires for nuclear mineral technology services. An assessment analysis of complaints handling, and suggestions by customers conducted to get feedback which used as capital to improve the quality of continuous service. Improving the quality of procedures and concrete actions to handle service complaints which submitted by all customers is an opportunity to improve the quality of continuous services so as to maintain the organization's long-term success.
\end{abstract}

Keywords: complaint, public services, the organization's long-term success, customers.

\section{Introduction}

Excellent service is a genuine key for a better future, for both customers and suppliers [1]. Efforts to connect good governance with public services may not be new. The connection between the concept of good-governance with the concept of public service certainly is clear enough logic [2]. Public services are chosen as the right way to realize good governance because in the implementation of public services involves the interests of all elements of governance, namely government, civil society and market mechanisms, so that it is considered to have a major influence on other aspects of government functions [3]. The government as the provider of public services is required to have a catalytic function, be able to empower the community, make efforts to encourage the spirit of competition, always oriented to the mission, prioritize and prioritize results rather than methods or processes, public interest as the main reference, entrepreneurial spirit, and always be anticipatory or try to prevent problems, are decentralized and market-oriented[4]. Public complaints are an expression of public dissatisfaction with the quality of services received which often leads to the birth of public demands, often seen as a bad thing for the life of an organization, including the bureaucracy [5]. Failures in service, and therefore complaints, are inevitable due to the number of variables and perceptions involved in service transactions [6]. Complaints are expensive, both as direct and indirect costs. Therefore in Deming cycle, that feedback and learning from mistakes were both key ingredients for achieving true TQM and sustained profitability [7]. If complaints are transformed into knowledge about customers, they can 
provide a valuable amount of capital for enterprises [8]. Good service organizations take complaints seriously [9]. Managing complaints well and recovering customers, i.e., dealing with them after a service failure and (usually) a complaint, should be the cornerstone of an organization's customer-satisfaction strategy [10]. Closely related to customer satisfaction which can reflect service quality. Orientation on customer fulfillment is the main focus that can measure the quality of goods and/or services provided [2]. A consumer or satisfied customer is a customer who feels he gets value from a manufacturer or service provider [11]. The attribute that is the topic of the paper is service. Service is any action or activity that can be offered by a party to another party, which is basically intangible and does not result in any ownership [12]. Service is the behavior of producers in order to meet the needs and desires of consumers in order to achieve customer satisfaction itself [11]. Consumer satisfaction is inseparable from how the organization manages complaints or complaints and suggestions [10]. This era, the company faces increasing levels of competition, as well as the challenges of increasingly rapid market evolution[13]. Encouraging customer complaints and making it easy for customers to register their dissatisfaction also had the benefit of letting the organizations know quickly when something was going wrong [9]. Organizational responses are the initial reactions by a company in response to a complaint [14]. This paper raises the issue of customer assessment of complaints services and suggestions by organizations on public services related to nuclear mineral technology.

The types of public services provided by nuclear minerals technology are in the form of visiting services to nuclear facilities and expert visits (K1), student and collage services for work practices and final assignments (K2), in addition to providing nuclear expertise services (K3) and processing services, exploration services (K4). In providing services firstly, precisely and with quality, service employee must understand the requirements, procedures, completion period, fee, and service products [15]. In addition to these elements, implementing competencies, implementing behavior, announcements of services and handling complaints, suggestions and inputs are things that must be considered by service providers [15]. The elements that are discussed in this paper are handling complaints, suggestions, and input.

Previous literature provided support that handling public complaints related to customer satisfaction and loyalty [14][16][17], service quality [7] and organizational performance [2][3][4]. Therefore an analysis of handling complaints assessment by customers of nuclear minerals technology needs to be done to obtain feedback which is then used as capital to improve the services quality continuously.

\section{Methodology}

Primary and secondary data were used in this research. A questionnaire was the tool to get the respondents answer. Respondents of this research were users of all types of services. Teachers, local government and IAEA experts are customers of facility visits and expert visits. Vocational high school (SMK) students and students from various levels are customers of student services for practical work and final assignments. State-owned enterprises and 
members of the Tanah Rare Metals (LTJ) consortium are customers of nuclear expertise services as well as mineral processing and exploration services. Previous research literature studies and applicable regulations are secondary data in this study. In addition, any research based on the measurement of variables must pay attention to accuracy and dependence [18]. Secondary data was used to determine the variables in the questionnaire, especially the mechanism for handling complaints / complaints, suggestions and input [15]. This study uses questionnaires as a form of quantitative approach descriptively to describe the characteristics of observational groups or can be used to draw conclusions, which use data from sample groups to make generalizations about larger groups or populations [19].

Data analysis of this study uses statistical methods with the Statistical Package for the Social Sciences (SPSS) program. Statistical analysis is a useful strategy that allows us to reduce the data collected into summary figures, thus enabling us to make meaning from the results of the assessment [19]. The statistical method used is descriptive frequency analysis. Descriptive statistics provide us with a useful strategy for summarizing data and providing sample descriptions but cannot provide information for causal analysis [19]. Frequency statistics are the main descriptive statistics used with discrete variables. These include absolute frequencies (raw quantities) for each category of discrete variables, relative frequencies (proportions or percentages of the total number of observations), and cumulative frequencies for successive categories of ordinal variables [20]. The determination of variables in this study is based on the mechanism for handling complaints / complaints, suggestions and input in accordance with PERKA BATAN No. 13 of 2017 concerning Public Service Standards. The variables analyzed can be seen in Table 1. The choice of answers in the questionnaire illustrates the level of customer acceptance of the mechanism for handling complaints / complaints, suggestions and input into service.

Table 1. Research Variables

\begin{tabular}{lc}
\hline \multicolumn{1}{c}{ Variables } & Code \\
\hline Availability of public services Complaint facilities & P1 \\
Whistleblower system & P2 \\
The person in charge / manager for handling public complaints is clear & P3 \\
Complaints procedures is clear & P4 \\
Certainty of follow-up on handling public service complaints is clear & P5 \\
Certainty follow-up on handling corruption and nepotism complaints is clear & P6 \\
\hline
\end{tabular}

\section{Result and Discussion}

Respondents in this survey were 71, who are users of all types of nuclear minerals technology public services. Data tabulation based on the type of service they use can be seen in Figure 1. Respondents fill out questionnaires based on their experience using nuclear minerals technology public services.

This questionnaire is intended to get responses from customers regarding the behavior of service personnel during service. The scale used is the ordinal scale which is a hierarchy so 
that all cases can be sorted from lowest to highest score (ranking by ranking) [19]. The ordinal scale on the questionnaire is from those who strongly agree with a value of 4 (four) to strongly disagree with a value of 1 (one). Strongly agree to show if the service variable in accordance with implementation, while strongly disagree illustrates that the service variable does not match those obtained by the customer.

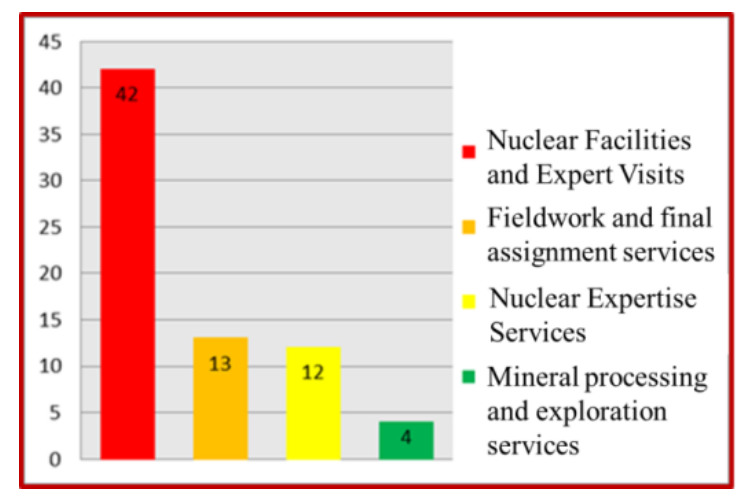

Fig 1. Respondents Tabulation Data

Respondents' answers for all service variables are 4 for the maximum value and 1 for the minimum value. The Summary of questionnaire results shown at Table 2.

Table 2. Summary of respondents answer

\begin{tabular}{ccccc}
\hline \multicolumn{5}{c}{ Table 2. Summary of respondents answer } \\
\hline Variable & $\mathrm{N}$ & Minimum & Maximum & Modus \\
\hline P1 & 70 & 1.00 & 4.00 & 4.00 \\
P2 & 5 & 2.00 & 3.00 & 3.00 \\
P3 & 70 & 1.00 & 4.00 & 4.00 \\
P4 & 71 & 1.00 & 4.00 & 4.00 \\
P5 & 71 & 1.00 & 4.00 & 4.00 \\
P6 & 4 & 2.00 & 4.00 & 3.00 \\
\hline
\end{tabular}

In a descriptive analysis of the frequency, arrangements and summarizes the data was presented in tabular form which lists data values that may be different (either individually or by grouping) together with the appropriate frequency, which represents the number of times these values occur. This frequency distribution will give a typical picture of how the data diversity [21]. The nature of data diversity is very important to know, because in subsequent statistical tests we must always pay attention to the nature of data diversity. Regardless of the nature of data diversity, drawing conclusions is generally invalid. Here are the results for each service variable. 
The first variable regarding the availability of service complaints facilities (P1), can be seen in Tables 3 , in the facility and questionnaire visits by experts (K1) as many as 23 respondents or $56.1 \%$ gave agreed ratings, 15 or $36.6 \%$ of respondents gave ratings strongly agreed, but there were also those who gave ratings that strongly disagreed as many as 2 respondents or $4.9 \%$ and $2.4 \%$ stated they did not agree. In the fieldwork service questionnaire and final assignment (K2) as many as 2 or $15.4 \%$ of respondents gave an assessment disagree to agree, but there were 10 or $76.9 \%$ of respondents gave an agreed rating. Nuclear Expertise Questionnaire (K3), the majority agree with a percentage of $75 \%$. In the processing services questionnaire and exploration services for nuclear minerals (K4) there is only 1 or $25 \%$ of respondents who disagree while 3 or $75 \%$ agree with complaints, suggestions and input services. Based on the overall results of the questionnaire data can be interpreted that the organization provides a complaint, suggestion and input service and its whereabouts are known to most customers. The second variable about the availability of whistleblowers system (P2). This variable is only presented in the processing services questionnaire and exploration services for nuclear quarrying material (K4). The results of the assessment can be seen in Table 3, as many as $75 \%$ of respondents agreed and $25 \%$ disagreed if a whistleblower was available. Based on these data, it can be interpreted that the majority of customers feel that the organization provides service of the whistleblowers system.

The third variable about the person in charge / manager of handling complaints (P3), the dominance of respondents' answers is to agree with the following details: $48.7 \%$ for $\mathrm{K} 1$, $84.6 \%$ for $\mathrm{K} 2,91.7 \%$ for $\mathrm{K} 3$ and $50 \%$ for $\mathrm{K} 4$. Based on data from the overall results of the questionnaire can be interpreted that the organization has assigned a responsible / manager to handle public service complaints to maintain the response of the customers [22]. The number can be seen at Table 3 . The fourth variable regarding the clarity of the complaints procedure (P4) can be seen in Tables 3, the majority of respondents for each type of questionnaire agreed, with details as follows: K1 questionnaire type was 50\%, K2 was $84.6 \%$, K3 was $91.7 \%$ and $\mathrm{K} 4$ was $50 \%$ of the population of respondents in each type of questionnaire, but it should be noted by the organization that there are still customers of $4.8 \%$ and $7.1 \% \mathrm{~K} 1,15.4 \%$ $\mathrm{K} 2$ and $25 \% \mathrm{~K} 4$ who disagree and strongly disagree. This indicates that there are still customers who do not understand the service complaints procedure. Therefore organizations need to evaluate the quality of applicable service procedures [7].

The fifth variable about the certainty of the follow-up on handling service complaints (P5) Tables 3, there was a small proportion of respondents giving an assessment of strongly disagree and disagree. With the following details as many as 2 respondents or $4.8 \%$ of respondents $\mathrm{K} 1$ stated strongly disagree, as much as 1 respondent or as much as $2.3 \%$ gave an assessment of not agree. For the type of K2 questionnaire as many as 2 respondents or as much as $15.4 \%$ gave an assessment disagree. Type of $\mathrm{K} 4$ questionnaire as many as 1 respondent or by $25 \%$ also expressed disagreement. This should be an evaluation of PTBGN, because not all customers feel real action to handle service complaints submitted by customers, so that it will affect customer loyalty [17] and satisfaction [16] in using services. The sixth variable about the clarity of the follow-up certainty in handling complaints of corruption and nepotism (P6), as shown at table 3, by $50 \%$ gave an agreeing assessment. This indicates that the majority of customers feel that the organization responds to complaints of corruption and nepotism. 
Table 3. The summary of data analysis

\begin{tabular}{ccccc}
\hline \multirow{2}{*}{ Variable } & \multicolumn{3}{c}{ Criteria } \\
\cline { 2 - 5 } & Strongly agree & Agree & Disagree & Strongly disagree \\
\hline P1 & 19 & 45 & 4 & 2 \\
P2 & 0 & 3 & 1 & 0 \\
P3 & 19 & 44 & 5 & 2 \\
P4 & 18 & 45 & 6 & 2 \\
P5 & 18 & 47 & 4 & 2 \\
P6 & 1 & 2 & 1 & 0 \\
\hline
\end{tabular}

The aim of the study was feedback from customers. The feedback used as a capital to sustainable improvement of services quality through analysis of customer assessment data on service complaints, suggestions and input. The data used came from the assessment of 71 respondents of service customers. All complaints, suggestions and input variables get positive ratings from the majority of customers, although there are some customers who give the opposite value.

\section{Conclusion}

Improving the quality of service procedures and concrete actions to handle service complaints submitted by all customers is feedback as capital for continuous improvement in the quality of nuclear technology services. Customers assess other variables as met. These results provide an opportunity to improve service performance by viewing complaints handling not only as an operational improvement factor but also as a determining factor for the long-term success of an organization. In other words, analyzing the handling of complaints, suggestions and input from customers has the opportunity to trigger continuous improvement in service quality so as to maintain organizational success.

\section{Acknowledgments.}

The authors would like to thank all the parties that participate in this research. Center for nuclear minerals technology for granting research permits.

\section{References}

[1] L. L. Zeithaml, V.A., Parasuraman, A. and Berry: Delivering Quality Service, Free Press. New York, NY., 1990.

[2] BAPPENAS: Manajemen Pengaduan Masyarakat dalam Pelayanan Publik, Lap. Kaji., 2010.

[3] S. Styawan: Penanganan Pengaduan ( Complaint Handling ) Dalam Pelayanan Publik 
( Studi Tentang Transparansi, Responsivitas, Dan Akuntabilitas Dalam Penanganan Pengaduan di Kantor Pertanahan Kota Surabaya II ), J. Ilmu Adm. Negara, vol. 1, no. 2, pp. 1-11, 2015.

[4] D. Hariani: Manajemen komplain dan penanganan keluhan dalam pelayanan publik, J. Ilmu Adm., vol. Vol.5, no., pp. 239-253, 2008.

[5] Suryadi:Penanganan Keluhan Publik pada Birokrasi Dinas Perijinan, Masyarakat, Kebud. Dan Polit., vol. 23, no. 4, pp. 293-303, 2010.

[6] W. E. Deming: Out of the Crisis, MIT Cent. Adv. Eng. Stud. Cambridge, MA., 1986.

[7] V. G. Bosch and F. T. Enríquez, "TQM and QFD: Exploiting a customer complaint management system," Int. J. Qual. Reliab. Manag., vol. 22, no. 1 SPEC. ISS., pp. 3037, 2005.

[8] V. Gonza'lez Bosch: La Administración de las Quejas como Capital de las Empresas (in Spanish), ITESM, Monterrey, 2001.

[9] R. Johnston and S. Mehra: Best-practice complaint management., Acad. Manag. Exec., vol. 16, no. 4, pp. 145-154, 2011.

[10] S. W. Tax, S. S., \& Brown: Recovering and learning from service failure. , Sloan Manage. Rev., vol. 40, no. 1, pp. 75-89, 1998.

[11] W. Mardikawati: LOYALITAS PELANGGAN , MELALUI KEPUASAN PELANGGAN PADA PELANGGAN BUS EFISIENSI ( Studi PO Efisiensi Jurusan Yogyakarta-Cilacap ), pp. 64-75.

[12] P. Kotler: Manajemen Pemasaran1, Millineum. Jakarta: PT.Prenhallindo, 2002.

[13] A. Ranchhod: How to Calculate the Value of a Customer Measuring customer satisfaction: A platform for calculating, predicting and increasing CUSTOMER SATISFACTION AND, vol. 10, pp. 203-219, 2002.

[14] K. Gelbrich and H. Roschk: A meta-analysis of organizational complaint handling and customer responses, J. Serv. Res., vol. 14, no. 1, pp. 24-43, 2011.

[15] P. Publik, T. L. Negara, and I. Tahun: Peraturan Mengenai Standar Pelayanan Publik; 2017.

[16] C. Orsingher, S. Valentini, and M. De Angelis: ORIGINAL EMPIRICAL RESEARCH A meta-analysis of satisfaction with complaint handling in services, pp. 169-186, 2010.

[17] C. Homburg and A. Fürst: Handling Drives Customer Loyalty: An Analysis of the Mechanistic and.

[18] M. Liphadzi, C. Aigbavboa, and W. Thwala: Relationship between Leadership Styles and Project Success in the South Africa Construction Industry, Procedia Eng., vol. 123, pp. 284-290, 2015.

[19] M. J. Fisher and A. P. Marshall: Understanding descriptive statistics, Aust. Crit. Care, vol. 22, no. 2, pp. 93-97, 2009.

[20] M. G. Larson: Descriptive Statistics and Graphical Displays, Circulation, vol. 114, no. 1, pp. 76-81, 2006.

[21] A. Setiawan: Distribusi Frekuensi, 2011. [Online]. Available: http://www.smartstat.info/statistika/statisika-deskriptif/distribusi-frekuensi.html. [Accessed: 16-Apr-2019].

[22] M. Davidow: Organizational Responses to Customer Complaints: What Works and What Doesn't, J. Serv. Res., vol. 5, no. 3, pp. 225-250, 2003. 